\title{
LZTR1 Gene
}

National Cancer Institute

\section{Source}

National Cancer Institute. LZTR1 Gene. NCI Thesaurus. Code C128257.

This gene may be involved in Golgi stabilization, embryogenesis or transcriptional regulation. 